\title{
Avaliação do kit SNAP 4DX na detecção de imunoglobulinas anti-Borrelia spp. em equinos nacionais naturalmente infectados
}

\footnotetext{
[a] Faculdade de Ciências Agrárias e Veterinárias, Universidade Estadual Paulista (UNESP), Jaboticabal, SP, Brasil

[b] Centro Universitário Central Paulista (UNICEP), São Carlos, SP, Brasil
}

*Autor correspondente

e-mail: talissadebonis@hotmail.com

\section{Resumo}

A Borreliose de Lyme é uma zoonose causada por espiroquetas do complexo Borrelia burgdorferi sensu lato, cujos reservatórios são os roedores, especialmente capivaras, podendo os animais domésticos atuarem como transportadores do patógeno. No Brasil há algumas diferenças em relação à doença descrita no hemisfério norte, sendo a principal as características morfológicas e genéticas atípicas apresentadas pelo agente etiológico. Devido a essas diferenças, a doença nacional foi nomeada como Borreliose de Lymesímile. Seu diagnóstico convencional é baseado em sorologia ELISA, Western Blot ou PCR (reação em cadeia da polimerase). 0 kit SNAP 4DX ${ }^{\circledR}$, fabricado pela IDEXX Laboratories, índustria inserida no mercado de diagnósticos para a saúde animal, foi utilizado com sucesso na detecção de imunoglobulinas G (IgG) antiBorrelia em cães e equinos infectados por B. burgdorferi stricto sensu provenientes dos Estados Unidos. Neste trabalho, objetivou-se comparar a eficácia do kit imunoensaio enzimático SNAP 4DX ${ }^{\circledR}$ em relação ao ELISA na detecção de IgG anti-Borrelia spp. em equinos nacionais naturalmente infectados, analisando sua sensibilidade e especificidade. Utilizamos 60 amostras de soro de equinos provenientes do estado de São Paulo, dos quais 30 foram classificados como soronegativos pelo ELISA por possuírem título inferior à $1 / 400$ e 30 soropositivos, pois apresentaram título igual ou superior a 1/400. Destes últimos, a distribuição com relação aos títulos obtidos no ELISA foi de dois animais com título 1/3200, quatro animais com 1/1600, 11 animais com 1/800 e 13 com 1/400. 0 teste foi realizado conforme instruções do fabricante. A maior sensibilidade/especificidade foi obtida ao se realizar a análise considerando como positivos somente os animais com título igual a 1/3200, no qual a sensibilidade foi de $100 \%$ e a especificidade de $74 \%$. Ao considerarmos positivos os animais com título igual ou superior a $1 / 1600$, a sensibilidade caiu para $50 \%$ e 
a especificidade ainda se manteve em 74\%. Se considerarmos positivos títulos iguais ou superiores a 1/400 como no ELISA, a sensibilidade do teste SNAP 4 DX ${ }^{\circledR}$ foi de $50 \%$ e a especificidade $93 \%$. A B. burgdorferi stricto sensu (hemisfério norte) provoca reações imunológicas mais consistentes nos equinos, geralmente promovendo títulos que variam entre 1/800 a 1/6400 em sua fase aguda. Como este kit foi formulado para este subconjunto das Borrelias, provavelmente sua sensibilidade menor nos equinos nacionais advenha deste aspecto. Além disso, sabe-se que as Borrelias spp. nacionais, que promovem a Doença de Lymesímile, são menos imunogênicas tanto em humanos quanto em animais, dificultando muito seu diagnóstico sorológico. 0 kit de imunoensaio SNAP 4DX ${ }^{\circledR}$ é pouco sensível para detecção de anticorpos anti-Borrelia spp nacionais, causadoras da Doença de Lyme-Símile, na maior parcela dos equinos naturalmente infectados. Porém, pode ser útil em casos agudos em que o título de anticorpos IgG seja superior a 1/1600.

Palavras-chave: Borreliose. Lyme-símile. Elisa.

Agradecimentos: ao Conselho Nacional de Desenvolvimento Científico e Tecnológico (CNPq). 